\title{
DEPENDENCE OF LAMB SENSORY PROPERTIES ON MEAT RIPENING LEVEL ${ }^{* *}$
}

\author{
S. Ivanović ${ }^{1}$, S. Savić ${ }^{2}$, M. Baltić ${ }^{3}$, V. Teodorović ${ }^{3}$, M. Žujović ${ }^{4}$ \\ ${ }^{1}$ Veterinary Institute of Serbia, Belgrade \\ ${ }^{2}$ Private Veterinary Station \\ ${ }^{3}$ Faculty of Veterinary Medicine, Belgrade \\ ${ }^{4}$ Institute for Animal Husbandry, Belgrade-Zemun \\ *Correspondin author: e-mail: sniva@ptt.yu \\ ** original scientific paper
}

Abstract: Sheep and lamb meat are in the first place by value, as sheep raising products. Sensory properties are important factor that influence on the meat safety. The aim of these investigations was to determine the influence of ripening level on odour, tenderness, softness, taste, flavour and overall acceptability of meat. As material in this experiment meat of lambs of "SvrljigPirot Pramenka" hybrids were used. Lambs were 5 months old at slaughtering. Meat was roasted in oven at temperature of $170^{\circ} \mathrm{C}$ for 60 minutes. As method the quantitative-descriptive analysis is used. Our results showed that meat ripening level influence on the acceptability of lamb meat and on expressiveness of some attributes that closer define sensory properties of meat (intensity, odour, tenderness, softness, taste and flavour).

Key words: lamb meat, sensory property, evaluation

\section{Introduction}

Sheep and lamb meat are in the first place by value, as sheep raising products. They are used by customers world wide in each cultures and religions, that is not case with pork and beef. In the other hand, some people do not accept this kind of meat due to specific odour and taste which are especially expressed during the thermal treatment. There is special sensation in the mouth during the mastication that defined as "on wax". However, Ivanovic et al. (2004) points that lamb is the product of characteristic odour and taste, high price and can be treated as luxurious product.

The acceptability of some product depends of its quality. Meat has very complex composition and definition of its quality is very complicated. According to Hofmann (1990) meat quality is consisted of hygienic, nutritive 
and sensory aspects (at first colour, texture, tenderness, softness and flavour). Meat quality is also influenced by the technological factors (Beriain, 2003).

Meisinger and Miler (1998) divided meat quality properties into two groups: visual and edible quality properties or meat palatability. These authors defined that visual characteristics of quality are influenced by: water holding capacity or loss of juice, meat colour, intramuscular lipids and glow. But the same authors have an opinion that visual characteristic of meat are consisted also of defects as are damages on places of applications of injections and bruises.

In edible characteristics of quality or meat palatability authors include softness, tenderness and taste.

Important meat properties are textural attributes (hardness, tenderness, softness etc.) that depend of animal species, race, age, sex and fattening (Schreurs, 1999), also of handling with meat (conditions of storage-ageing and thermal treatment).

The flavour is one of the most important factors in determination of meat acceptability by consumers. Basic flavour of meat relates to components soluble in water as are carbohydrates, amino acids and nucleotides that are characteristic for animal species. Characteristic flavour of meat in various species is influenced by proportion of fatty acids in lipids, especially of unsaturated fatty acids that are more liable to oxidation than others and by volatile components with low molecular weight as are aldehydes, ketons, carbohydrates and alcohols. Content of carbohydrates in muscles after slaughtering is relative low $-0.5-1.5 \%$. In muscles where the glucolysis is intensive post mortem there is very low amount of glycogen, but meat has intermediate products of metabolism: hexoso-phosphates, triozo-phosphates, piruvat and citric acid and significant amount of lactic acid (1\%).

Carbohydrates are presented also in glycoproteins and mucopolisaharides of connective tissue (Vukovic, 1998). Phospholipides that are rich in unsaturated fatty acids also play fundamental role in development of meat flavour. Wagner (1986) divided factors that influence meat flavour in three groups: genetic factors (species, race and sex), breeding factors (feeding, age, treatment with animals before slaughtering) and factors influenced by treatment with meat (conditions of storage - ageing and thermal treatment). This author noted that younger animals have less expressed flavour than older.

Some authors maintain the flavour means taste and odour of meat (Young et al., 1997). According to that the sensory properties are the important factor that influence quality, the aim of this paper was to determine the influence of ageing level on odour, tenderness, softness, taste, flavour and overall acceptability of lamb meat. 


\section{Material and methods}

As material in this experiment the meat of lamb of "Svrljig-Pirot Pramenka" is examined. Lamb was 5 months old at slaughtering. They were fed milk, pasture and concentrate was added to their diets.

Meat from shoulder was thermally treated in the oven at $170^{\circ}$ for 60 minutes. The amount of sample that each evaluator got was $50 \mathrm{~g}$, although USA - Committee for sensory evaluation of food recommend that $28 \mathrm{~g}$ is enough to evaluate the odour and taste (Baltic, 1994).

In experiment the sensory methods were used in which participated 8 trained assessors. For quantitative-descriptive analysis (ISO 6564/85), the structure scales of intensity with 7 points were used. It was assessed the intensity of odour, tenderness, softness, intensity of taste, flavour acceptability and overall acceptability (Baltic, 1994). Better attributes evaluated with higher number.

Obtained results were statistically assessed calculating mean and variations parameters (standard deviation, variation coefficient) and t-value for determination of significance of differences between average values of sensory properties between groups (hypothesis of equal means).

\section{Results and discussion}

Before thermal treatment, the odour and taste of lamb were assessed as desirable and distinctive for this meat.

The results of sensory evaluation are presented in tables 1,2 and 3.

Tabela 1. Senzorna ocena mesa jagnjadi (zrenje jedan dan)

Table 1. Sensory evaluation of lamb meat (ripening one day)

\begin{tabular}{||l|c|c|c|c|c|c||}
\hline \hline $\begin{array}{l}\text { Svojstvo/ } \\
\text { Property }\end{array}$ & $\bar{X}$ & $\mathbf{S d}$ & $\mathbf{S e}$ & $\mathbf{X}_{\max }$ & $\mathbf{X}_{\min }$ & $\mathbf{C v \%}$ \\
\hline \hline Miris mesa/Meat odour & 4,79 & 0,20 & 0,06 & 5,1 & 4,5 & 4,18 \\
\hline $\begin{array}{l}\text { Mekoća mesa/meat } \\
\text { tenderness }\end{array}$ & 4,31 & 0,22 & 0,07 & 4,7 & 4,5 & 5,10 \\
\hline Sočnost/ juiciness & 4,08 & 0,29 & 0,09 & 4,5 & 3,6 & 7,10 \\
\hline Ukus mesa/ taste & 4,46 & 0,20 & 0,06 & 4,7 & 4,1 & 4,48 \\
\hline Aroma mesa/Aroma & 4,58 & 0,16 & 0,05 & 4,8 & 4,3 & 3,49 \\
\hline $\begin{array}{l}\text { Ukupna prihvatljivost/ } \\
\text { overall acceptibility }\end{array}$ & 4,22 & 0,22 & 0,07 & 4,5 & 4,0 & 5,21 \\
\hline
\end{tabular}


Tabela 2. Senzorna ocena mesa jagnjadi (zrenje tri dana)

Table 2. Sensory evaluation of lamb meat (ripening two days)

\begin{tabular}{|l|c|c|c|c|c|c||}
\hline $\begin{array}{l}\text { Svojstvo/ } \\
\text { Property }\end{array}$ & $\bar{X}$ & $\mathbf{S d}$ & $\mathbf{S e}$ & $\mathbf{X}_{\max }$ & $\mathbf{X}_{\min }$ & $\mathbf{C v} \%$ \\
\hline \hline Miris mesa/Meat odour & 5,35 & 0,32 & 0,06 & 5,8 & 4,8 & 5,98 \\
\hline $\begin{array}{l}\text { Mekoća mesa/meat } \\
\text { tenderness }\end{array}$ & 6,42 & 0,27 & 0,09 & 6,8 & 4,8 & 4,21 \\
\hline Sočnost/ juiciness & 5,12 & 0,30 & 0,10 & 5,6 & 4,7 & 5,86 \\
\hline Ukus mesa/ taste & 5,29 & 0,27 & 0,09 & 5,5 & 4,8 & 5,10 \\
\hline Aroma mesa/Aroma & 5,45 & 0,38 & 0,12 & 6,0 & 4,8 & 6,97 \\
\hline $\begin{array}{l}\text { Ukupna prihvatlivost/ overall } \\
\text { acceptibility }\end{array}$ & 5,87 & 0,16 & 0,06 & 6,0 & 5,5 & 2,73 \\
\hline
\end{tabular}

Tabela 3. Senzorna ocena mesa jagnjadi (zrenje sedam dana)

Table 3. Sensory evaluation of lamb meat (ripening seven days)

\begin{tabular}{||l|c|c|c|c|c|c||}
\hline $\begin{array}{l}\text { Svojstvo/ } \\
\text { Property }\end{array}$ & $\bar{X}$ & Sd & Se & $\mathbf{X}_{\max }$ & $\mathbf{X}_{\min }$ & $\mathbf{C v} \%$ \\
\hline \hline Miris mesa/Meat odour & 5,64 & 0,39 & 0,12 & 6,0 & 4,8 & 6,92 \\
\hline $\begin{array}{l}\text { Mekoća mesa/meat } \\
\text { tenderness }\end{array}$ & 6,55 & 0,22 & 0,07 & 6,9 & 4,8 & 3,36 \\
\hline Sočnost/ juiciness & 5,18 & 0,34 & 0,11 & 5,6 & 4,9 & 6,56 \\
\hline Ukus mesa/ taste & 5,20 & 0,23 & 0.07 & 5,5 & 5,0 & 4,42 \\
\hline Aroma mesa/Aroma & 5,43 & 0,30 & 0,10 & 5,8 & 5,0 & 5,53 \\
\hline $\begin{array}{l}\text { Ukupna prihvatljivost// } \\
\text { overall acceptibility }\end{array}$ & 5,61 & 0,17 & 0,05 & 6,0 & 5,5 & 3,03 \\
\hline
\end{tabular}

By quantitative-descriptive analysis it was determined that the average evaluations of odour intensity were $4.79 \pm 0.20,5.35 \pm 0.32$ and $5.64 \pm 0.39$ in the first, third and seventh day of ripening, respectively. Between average values of odour intensity it is found significant differences for all days of examinations ( $p$ $\leq 0.01)$ and between the third and seventh day were less significant $(\mathrm{p} \leq 0.05)$. After one day of storage tenderness of meat was $4.31 \pm 0.22$, after three day $6.42 \pm 0.27$ and after seven day $6.55 \pm 0.22$, respectively. The difference between evaluations was very significant $(\mathrm{p} \leq 0.01)$ for the first, third and seventh day of ageing, respectively and between three and seven days was not significant $(\mathrm{p} \geq$ $0.05)$.

Sensory evaluation of softness after one day was $4.08 \pm 0.29$, after three day $5.12 \pm 0.30$ and after seven day $5.18 \pm 0.34$. Between samples stored one, 
three and seven days is noted statistical difference $(p \leq 0.01)$, but between three and seven days did not $(\mathrm{p} \geq 0.05)$.

The softness of lamb meat is expressed and depends of ability of muscles to keep own and bind added water (Vukovic, 1998). The softness mainly depends of meat processing as are cooling, freezing and culinary treatment. Meat that has good ability of holding the own water, during the thermal treatment retains more water and consecutive that meat is more soft. Hawkins et al. (1985) did not found the influence of race on water holding capacity of meat. However, Horcada et al. (1998) noted that this ability is less in meat of older animals that directly influence the softness.

Average values for taste of meat were after one day $4.46 \pm 0.20$, after three $5.29 \pm 0.27$ and after seven day $5.20 \pm 0.23$, respectively. Between these values it was found significant difference $(\mathrm{p} \leq 0.01)$. Between average evaluations for taste between three and seven day did not found statistically significant difference $(\mathrm{p} \geq 0.05)$.

After one day of storage the sensory evaluation of meat flavour was $4.58 \pm 0.16$, after three $5.45 \pm 0.38$ and after seven days $5.43 \pm 0.30$, respectively. Between samples stored one, three and seven days, the differences were very significant $(\mathrm{p} \leq 0.01)$ and between three and seven days did not found statistically significant difference $(\mathrm{p} \geq 0.05)$.

In the tables are shown the results of sensory evaluation of overall acceptability of meat depends of ageing level. After one day of storage, evaluation was $4.22 \pm 0.22$, after three days $5.87 \pm 0.16$ and after seven $5.61 \pm 0.17$, respectively. Between samples stored one and three and seven days, the difference in evaluations was very significant $(p \leq 0.01)$ and also between three and seven days of ageing.

Our results show that duration of ageing has positive influence on acceptability of lamb meat, also on expressiveness of some attributes that nearly define sensory properties of meat (intensity of odour, tenderness, softness, taste and flavour).

Other authors (Wagner, 1986; Young, 1997) emphasise that meat ageing has importance for intensity of taste, tenderness and softness of meat, also meat flavour. Right after slaughtering meat is tender and during rigor mortis it becomes harder (Vukovic, 1998). During the meat storage, due to proteolysis sarcomere structure are damaged and meat becomes more tender. Hydrolytic processes during ageing also can be assumption of increase of flavour after thermal treatment (Hornstein, 1971; Ouali, 1991). Tenderness is except by level of ageing also influenced by factors of technology of cooling of meat (Morbidini, 1994). 


\section{Conclusions}

1. Lamb meat quality is defined by odour, tenderness, softness, taste and by flavour. Colour and odour of meat used in these examinations were distinctive for lamb meat. Meat stored seven days did not show spoilage signs.

2. After thermal treatment, the odour of meat was the most expressible in meat stored seven days.

3. The most tender and the most soft meat was after seven days of ageing.

4. According to assessors, the best taste had meat after three days of ageing.

5. Specific flavour of lamb meat is the most expressible in meat after three days of storage.

6. The overall acceptability, as very complex attribute, depends of several factors, is influenced by volatile compounds of meat, that individually have very low limit of detection, but together or in combination with other sensory attributes it is evaluated that meat was the most desirable after three days of storage.

\section{Zavisnost senzornih osobina jagnjećeg mesa od stepena zrenja mesa}

Snežana Ivanović, S. Savić, M. Baltić, V. Teodorović, M. Žujović

\section{Rezime}

Ovčije i jagnjeće meso su po vrednosti, među proizvodima ovčarstva na prvom mestu. Senzorne osobine su važan činilac koji utiče na higijensku ispravnost mesa. Cilj našeg ispitivanja je bio da utvrdimo uticaj stepena zrenja mesa na miris, mekoća, sočnost, ukus, aromu i ukupnu prihvatljivost mesa. Kao materijal u ovom eksperimentu korišćeno je meso jagnjadi meleza svrljiškopirotske pramenke. Jagnjad su bila stara pet meseci prilikom klanja. Meso je obradjeno toplotom u pećnici pri temperaturi od $170^{\circ} \mathrm{C}$ u trajanju od 60 minuta. Metoda ispitivanja je kvantitativna deskriptivna analiza. 
Naši rezultati pokazuju da stepen zrenja utiče na prihvatljivost jagnjećeg mesa a takođe i na izraženost pojedinih atributa koji bliže definišu senzorne osobine mesa (intenzitet, miris, mekoća, sočnost, ukus i aroma).

Ključne reči: jagnjeće, meso, senzorsna osobina, ocena

\section{Literature}

BALTIĆ M. (1994): Kontrola namirnica, Institut za higijrnu i tehnologiju mesa, Beograd.

BERIAIN M.J., BAS P.,. PURROY A., TREACHER T. (2003): Effect of animal and nutritional factors and nutrition on lamb meat quality, http://ressources.ciheam.org/om/pdf/c52/00600313.pdf

HAWKINS R.R., KEMP J.D., ELY D.G., FOX J.D., MOODY W.G. and VIMINI R.J. (1985): Carcass and meat characteristics of crossbred lambs born to ewes of different genetic types and slaughtered at different weights. Livest. Prod. Sci., 12: 241-250.

HOFMANN K. (1990). 36th ICoMST, Proceedings III, 941, Havana, Cuba.

HORCADA A., BERIAIN, M.J., PURROY, A., LIZASO, G. AND CHASCO, J. (1998): Effect of sex on meat quality of Spanish lamb breeds (Lacha and Rasa Aragonesa). Anim. Sci., 67: 541-547

HORNSTEIN I. (1971): Chemistry of Meat Flavor. The Science of Meat and Meat Products, Freeman \& Co., San Francisko.

IVANOVIĆ S., LILIĆ S., ŽUJOVIĆ M., PAVLOVIĆ I. (2004) Organoleptičke osobine jagnjećeg mesa-faktor kvaliteta. Veterinarski glasnik, 58, 3-4, 350-358.

MEISINGER D., MILER R. K., (1998). Pork Qualiti Isues, 29-32. National Pork Producers Council, Des Monies, IA

MORBIDINI L., PANELlA, F., SARTI, D.M., SARTI, F.M., DROZDZ, A. AND CIURUS, J.( 1994): Slaughtering characteristics and carcass quality of export polish mountain lambs. 45th EuropeanAssociation of Animal Science, Edinburgh, 4-9 September.

OUALI A. (1991): Sensory quality of meat as affected by muscle biochemistry and modern technologies. In: Animal Biotechnology and the Quality of Meat Production, Fiems, L.O.

SCHREURS F.J.G. (1999): Postmortem changes in chicken muscle: some key biochemical processes involved in the conversion of muscle to meat. $\mathrm{Ph} \mathrm{D}$ thesis, University of Wageningen, Wageningen, The Netherlands.

VUKOVIĆ K.I. (1998): Osnovne tehnologije mesa. Veterinrska komora, 
Beograd 126-128.

YOUNG, O.A., BERDAGUE, J.L., VIALLON, C., ROUSSET-AKRIM, S. AND THERIEZ, M. (1997): Fat-borne volatiles and sheep meat odour. Meat Sci., 45: 183-200.

WAGNER H. (1986): Aromabildende Stoffe in Fleisch. Chemischphysicalische Merkmale der Fleischqualitat. Kulmbacher Reihe, Bd. 6, Kulmbah, 111. 